Article

\title{
Vertical Gardens: Sustainability, Youth Participation, and the Promotion of Change in a Socio-Economically Vulnerable Community in Brazil
}

\author{
Waleska Carolina do Valle Santos ${ }^{1, *}$, Diandra Singh ${ }^{2}$, Livia Delgado Leandro da Cruz ${ }^{1}$, \\ Luis Paulo de Carvalho Piassi ${ }^{1}$ (D) and Giuliano Reis ${ }^{2} \mathbb{D}$ \\ 1 School of Arts, Science and Humanities, University of Sao Paulo, 1000 Arlindo Bettio Street, Vila Guaraciaba, \\ São Paulo-SP 03828-000, Brazil \\ 2 Faculty of Education, Main Campus, University of Ottawa, 145 Jeans-Jacques-Lussier Private, \\ Ottawa, ON K1N9A7, Canada \\ * Correspondence: waleska.santos@usp.br
}

Received: 19 February 2019; Accepted: 11 June 2019; Published: 26 June 2019

\begin{abstract}
This article is situated within the intersection of education for social transformation (EST) and ecojustice education (EJE). We have described the benefits of youth participation in an after-school science program offered to socio-economically vulnerable populations in São Paulo (Brazil). More specifically, we explored participants' changing views of sustainability as they engaged in a 24-week project of their choice: The cultivation of a vertical herb garden. The analysis of our discussions and extensive field notes revealed that during the time participants cared for the garden, they developed: (a) A more accurate (refined) conceptualization of sustainability, (b) an appreciation for alternative and viable ways of producing food in urban settings, and (c) a stronger relationship with one another. In the end, involvement in the vertical garden project proved to be a powerful example of how science education can transform the livelihood of youth by expanding their views on human interconnectedness with all forms of life.
\end{abstract}

Keywords: education for social transformation; science education; ecojustice education; marginalized youth; vulnerable youth; Science Stand; São Paulo; Brazil

\section{Introduction}

The United Nations has explicitly stated the need to "improve the capacity of our education systems to prepare people to pursue sustainable development," especially the younger generations that are recognized as "the custodians of the future" [1]). Inherent in this affirmation is the belief that solutions to a number of socio-environmental maladies of our contemporary society-e.g., rampant consumerism, climate change, poverty, food insecurity, pollution, and animal abuse, to name a few-can be achieved through education. This is especially relevant to the field of science education, which is historically associated with the study of planet Earth and its inhabitants [2,3].

Our study is situated within the intersection of education for social transformation (EST) and ecojustice education (EJE). It examined the benefits of youth participation in an informal after-school science education program at the Youth Centre (pseudonym). This initiative is part of a larger community-based project known as Science Stand, which seeks to promote science in non-formal learning settings and to encourage youth from low-income communities to implement socio-environmentally sustainable actions in their neighborhoods [4].

More specifically, we examined the circumstances and events associated with a group of socio-economically vulnerable Brazilian adolescents while tending to a vertical herb garden that they chose to grow, over a 24-week period. In particular, we sought to investigate participants' 
changing understanding of sustainability over the duration of the project. The main questions we attempted to answer were: Can participants' exposure to sustainability issues and engagement in a sustainability project of their choice shape their views on sustainability? If so, how? Are there other potential benefits - if any — of youth participation in such activities?

In what follows, we first provide a description of the Science Stand project. Next, we outline the social context of the Youth Center, where the vertical garden project took place. We then offer an explanation as to why this project lies at the intersection of EST and EJE, after which we describe the vertical garden project itself, the research methods used, and the main findings. We conclude our paper by highlighting how participants' seemingly modest act of caring for the contained herbs that hung on a wall of the Youth Centre not only expanded their views on sustainability, but also empowered them to engage in sustainable practices and increased their personal bonds with one another.

\section{The Science Stand Project}

The Science Stand project has its origins in a number of earlier initiatives designed to engage learners in science. Two such initiatives in particular-the Experimentoteca-Ludoteca of the Institute of Physics at the University of São Paulo [5] and the ABC on Scientific Education-Hands-on program [6] an inquiry-based science education program inspired by the world-renowned French educational program La Main à la Pâte [7] —inspired a group of researchers at the University of São Paulo to develop a program aimed at making science accessible to a greater number of people, especially young learners in low-income communities. Drawing upon informal educational strategies [8] such as playfulness, critical thinking, and creativity [9], the idea of taking science out of the classroom and making it mobile [10] led to the origination of the Science Stand.

Consisting of two portable newsstand-like trailers (Figure 1) that were donated by the nongovernmental organization EDUCARE (https://www.redeeducare.com.br/), which makes it possible to create itinerant activities that can be taken virtually anywhere, Science Stand now operates across São Paulo in a variety of locations-public schools, youth centers, and other settings like city squares, parks, streets, and subway stations. The project is administered by teams of university students and professors in three different public higher education institutions: USP (University of São Paulo-a state university), UNIFESP (Federal University of São Paulo), and IFSP (Federal Institute of São Paulo). The actions described here refer to those activities carried out by the USP research team.

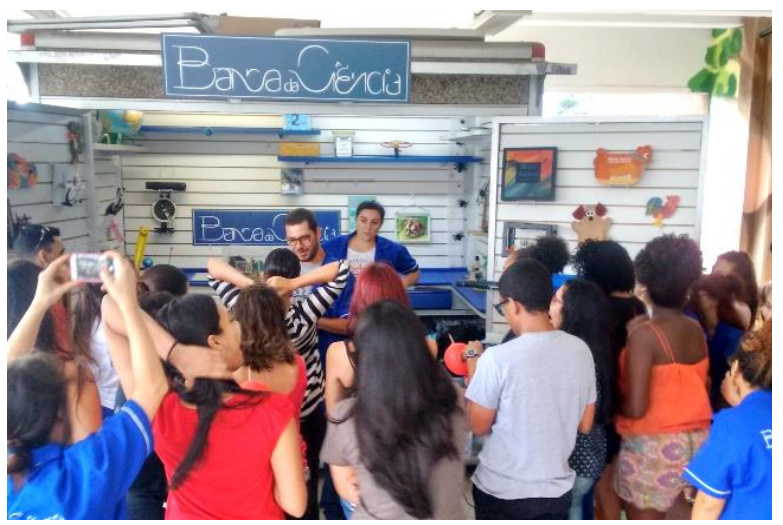

(a)

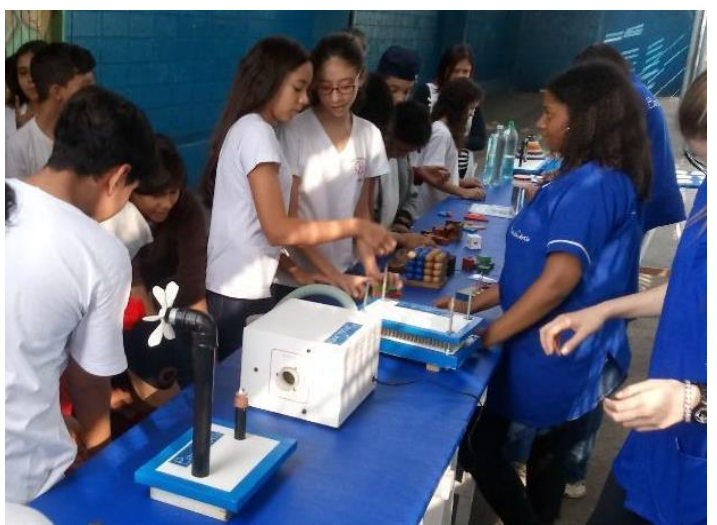

(b)

Figure 1. (a) Newsstand of the Science Stand Project at the University of São Paulo (USP) campus (b) A temporary stand set up for a demonstration in a.

Under supervision of one of the authors (Piassi), the Science Stand program at the University of São Paulo is delivered by students who are enrolled in the Natural Sciences Teaching Program, the Public Policy Management Program, and the Environmental Management Program. Different groups of students design different science demonstrations for different localities. The criteria for 
all demonstrations are that they be inexpensive, playful, and entertaining. The activities entail the use of affordable materials (e.g., planting in reused bottles) as well as the incorporation of artistic and media-based resources (e.g., films, comics, games, songs, pictures, etc.) in order to foster a fun learning environment. The project also promotes recreational practices aimed at empowering learners to think about ways of addressing socio-cultural issues, such as gender disparity in science and animal rights [11]. Finally, for instance, the vertical garden project had a team of 10 undergraduate students.

In addition to these pedagogical aspects, an educational goal of the Science Stand has been to elicit insights into practices that highlight the social, political, economic, and cultural factors of science. Accordingly, university students coordinate research projects on content, instructional strategies, gender equality issues, and participants' reactions to-and community involvement with-Science Stand activities. The findings are then used to improve programming and to expand knowledge in various contexts within which the Science Stand activities have taken place. One such activity was the vertical garden project which was implemented in the Youth Centre (YC).

\section{Context of the Youth Center}

The YC is a rented two-story house managed with public funds and located in a neighborhood with high social vulnerability in Greater São Paulo, the largest metropolitan area in Brazil with an estimated population of over 12 million people [12]. Only three streets in the neighborhood are paved and squatters occupy most of the properties. Access to the area is difficult since it is located just between a highway and a train line, which also generates noise pollution. In addition, the area faces several environmental problems related to the clandestine disposal of contaminated soil by a local factory that has exacerbated the social and health-related vulnerability of the neighborhood. Approximately $80 \%$ of the population is defined as low income residents, and most of the remainder lives in extreme poverty, receiving an estimated quarter of the national minimum wage, or about \$125 USD per month [13].

The educational level of those living in the area is much lower than elsewhere in São Paulo: $52 \%$ of the residents have not completed elementary education, $18.2 \%$ have not completed high school, and less than $2 \%$ have completed higher education [13]. This situation points to the need for closer academic ties between the local university (University of São Paulo) and the community to increase interest in/valorization of schooling. In this context, the work of the Science Stand can be seen as continually offering opportunities for youth in the community to connect to university students who can then serve as mentors.

Despite its cramped quarters, the YC has a playroom, a video library, an office, a dining room, a kitchen, and an improvised sports court, located on the roof. It lies in close proximity to the School of Arts, Science, and Humanities at one of the USP campuses, which was a determining factor facilitating the university-YC partnership in the vertical garden project. The YC aims to serve children and adolescents between ages six and 14 who experience various forms of vulnerability, such as fundamental rights violations (e.g., child labor), disabilities, or dependence on federal government income transfers. The YC's mission is to offer social protection to children and adolescents, develop their potential, provide support for the achievement of their autonomy and citizenship, and strengthen their ties with family and the community. To achieve these ends, the YC constitutes a space of coexistence based on the interests and demands of the children and youth who constitute their target audience [14].

\section{Intersecting Education for Social Transformation (EST) and Ecojustice Education (EJE)}

The vertical garden project is theoretically situated at the intersection of EST [15] and EJE [16]. Both of these theoretical frameworks enabled us to contextualize the socio-environmental circumstances of this project and to inform our understanding of the implications of the project for participants. Here we briefly describe the key tenets of each theoretical framework prior to describing their intersection in this project.

EST involves problematizing societal issues and taking subsequent action to address these issues. It is based on the recognition that society is replete with inequities (e.g., racism, classism, ableism, 
sexism, exploitation, etc.) that are constantly being reproduced through established social structures and policies. State schooling in particular has often been criticized for its complicity in perpetuating social injustice through the predominance of White Eurocentric patriarchal curricula [17]. To counter the status quo of mainstream education, the central aim of EST is for students to recognize injustice and promote actions against systemic oppression. Through EST, citizens on the margins can be empowered to bring about systemic change $[18,19]$.

In similar fashion, EJE is an approach to teaching and learning that acknowledges the world as a site of domination, particularly that of humans over all animals, plants, and ecosystems [16]. It proposes that all forms of domination-ecological and social-have resulted from two ideological stances: Hierarchical thinking, which is the idea that one is better than another; and a logic of domination, which is the belief that a certain group is entitled to or has dominion over another. In challenging these ideologies, EJE enables all, even those well-intentioned, to recognize their collusion with injustices that are taken-for-granted as social norms and to make changes to counteract them. The process of counteraction consists of connecting learning with activism, e.g., publicly protesting injustice, reinvigorating the commons, and creating community gardens [20,21].

EJE also requires people to think critically about dominant cultural norms (e.g., fewer girls attending Science Stand demonstrations because they are required to help at home) and how they lead to injustice (e.g., girls missing out on learning ways of mobilizing progressive social change and sustainable practices). EJE starts with the premise that the well-being of other life forms and their habitats are as important as those of humans. This requires a paradigm shift that is not readily supported by mainstream educational systems that continue to reinforce the status quo.

\section{The Vertical Garden Project}

As a pragmatic initiative that addresses socio-ecological injustices, the vertical garden project is one component of the Science Stand program that encapsulates aspects of both EST and EJE. It serves as a solution to the inadequate access to quality science education for people with a low socioeconomic status and their resulting underrepresentation in science fields. Similar to other initiatives within the Science Stand program, it embodies the educational aims of both EST and EJE by supporting the learning endeavors of marginalized youth and empowering them to critically understand how the social value of the natural world can create change in their communities.

The vertical garden project was initially designed as a three-part case study that involved 23 adolescents: Four females and 19 males, whose ages ranged from 11 to 14 . Our main research questions were: What are participants' views on sustainability? Can exposure to sustainability issues and participation in a sustainability-oriented project shape those views? If so, how? What are other potential benefits-if any—of youth participation in such activities?

The first phase of the study involved a preliminary activity to assess participants' beliefs about sustainability. The research team used didactic play-oriented interventions, using images related to sustainability, in order to foster adolescents' critical reflection on the meaning of sustainability. In small groups of up to six adolescents, participants looked at images representing unsustainable practices that are contrary to several of the UN's Sustainable Development Goals (SDGs) (Figure 2). Each one of the SDGs was paired with a conflicting image. After examining all the images, the participants discussed how they related (or not) to the idea of sustainability, offering evidence to support their answers. The conversations were audio-recorded and at times video-recorded. In addition, extensive field notes were taken. Data analysis focused on the meanings of sustainability that were expressed during the conversations and whether their views changed during the conversations, and in what ways. We also examined participants' levels of engagement (e.g., did they add other topics to the discussion? Were they bored? Were they comfortable?). 


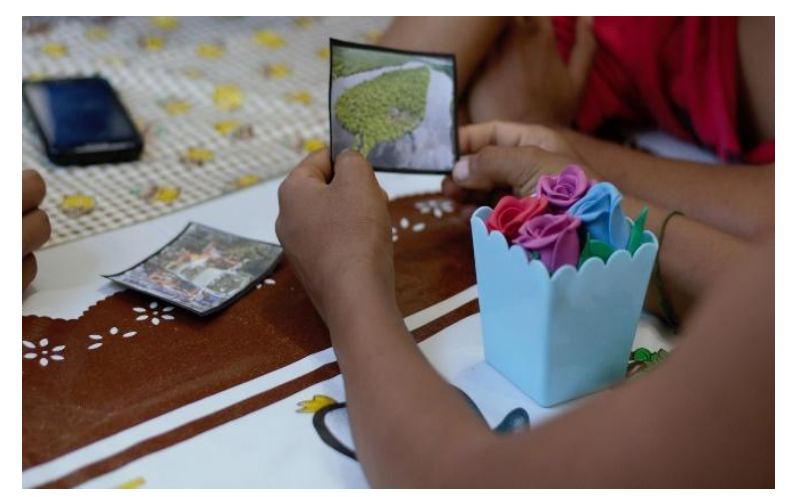

Figure 2. A participant looking at a sustainability image.

During the second phase, we utilized youth-friendly resources from the UN's website to supplement participants' views on sustainability and invited them to create their own sustainability-related project. First, the adolescents were asked if they were familiar with the 2030 SDG Agenda (Figure 3). Next, they watched a video called "Smurfs for the SDGs", which was created by the United Nations (UN) to promote the 17 sustainable development goals of the 2030 Agenda. After watching the video, participants answered a quiz (composed of four questions about the SDGs available on the Smurfs' website) [22] and their responses generated a critical discussion of one of the SDGs highlighted in the "Smurf Squad". Extrapolating from this discussion, the participants then turned their attention to considerations of how they could enhance their own community environment. This discussion led the youth to decide to create a vertical herb garden, which became the third phase of this project.

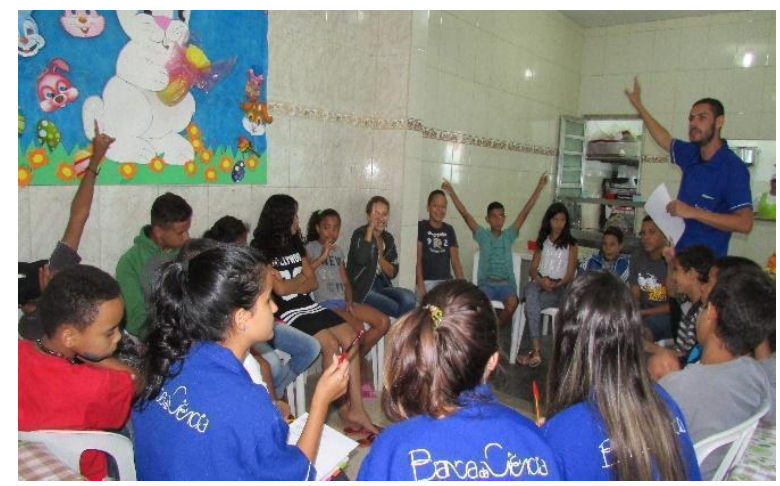

Figure 3. Participants discussing the 17 Sustainable Development Goals (SDGs).

The researchers gave the adolescents kits that contained soil, stones, a bottle, a seedling, seeds, and a spoon and instructed them on how to plant and take care of their herbs-from seedlings to adult plants. The seeds-mint, chives, parsley, and coriander-were selected as the best for summer planting (Figure 4). The youth participants worked in pairs to plant seeds and a grown plant in the same bottle, thus allowing them to make comparisons between the plants at different stages of their life cycle and to monitor the herbs' growth in relation to specific environmental (weather) conditions. Notably, participants chose to use PET (Regular plastic bottles made up from Polyethylene Terephthalate (PET)) bottles as containers for the herbs, a fitting sustainable action corresponding to the project goals. YC participants were responsible for caring for their plants every week (Figure 5). Some plants had to be watered almost every day (parsley) while others had to be watered less frequently (coriander). All the activities were monitored and assisted by the YC staff and the Science Stand research team. Throughout the construction and maintenance of the vertical garden, the research team debriefed at the end of each day and compared their observational and interview notes taken at different times during the project. 


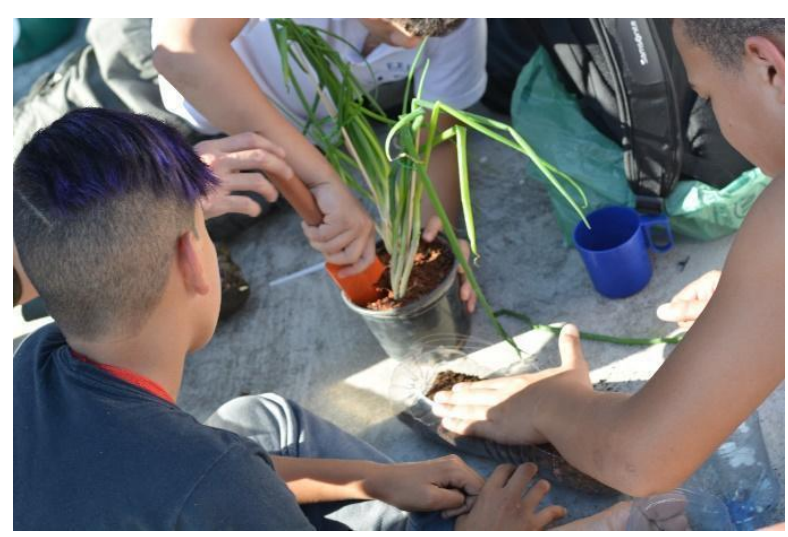

Figure 4. Planting for the first time.

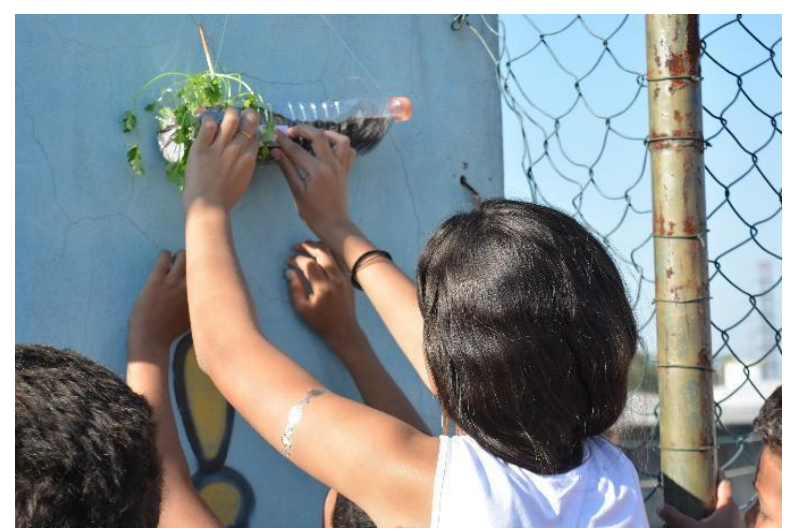

Figure 5. A participant taking care of her herb in the vertical garden.

\section{Adolescents' Perspectives of Sustainability (Phase 1)}

The way an image is interpreted represents the observer's point of view toward a specific subject and relates directly to the observer's personal experiences. It also provides information on the space in which the observer lives since that will affect the interpretation of the image [23]. The fact that participants live in a region that is stricken with poverty was expected to influence the ways they interpreted the images. For instance, Figure 6 [24] was interpreted by the adolescents as a child who did not have enough money for his basic needs, like food. Although they also pointed out that the child in the picture was not acting sustainably because he seemed to be wasting water, they also said that the child might have been trying to save money on the electricity bill by not taking a hot shower.

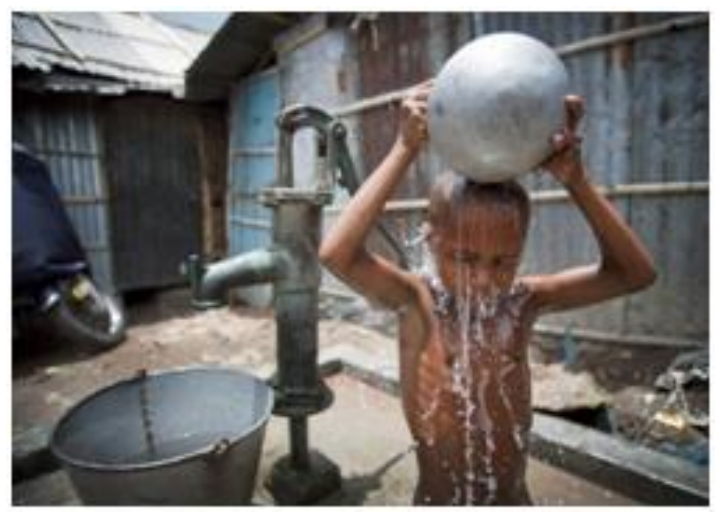

Figure 6. Child bathing in Kallayanpur, a poor neighborhood of Bangladesh. 
These selected images enabled the adolescents to assess particular situations and decide if they depicted sustainable practices or not. Their explanations shed light on their perspectives on different economic, social, and environmental contexts and the extent to which they regarded them as sustainable, thus yielding insights into their understanding of sustainability.

Initially, participants defined sustainability as the ability to financially sustain a family or one's healthy living: "I think sustainability is when, for example, my dad goes to work to make money to be able to sustain the family" (Nicholas). However, as their perceptions of the meaning of the term "sustainability" were broadened during the development of the project, they began to perceive sustainability as the human actions that in turn relate directly to environmental degradation and socio-economic inequality.

Figure 7 [25] was said to represent a junkyard or workers making money to support their families. Even though some of the group members posited that the picture was related to nature, they did not elaborate further on it.

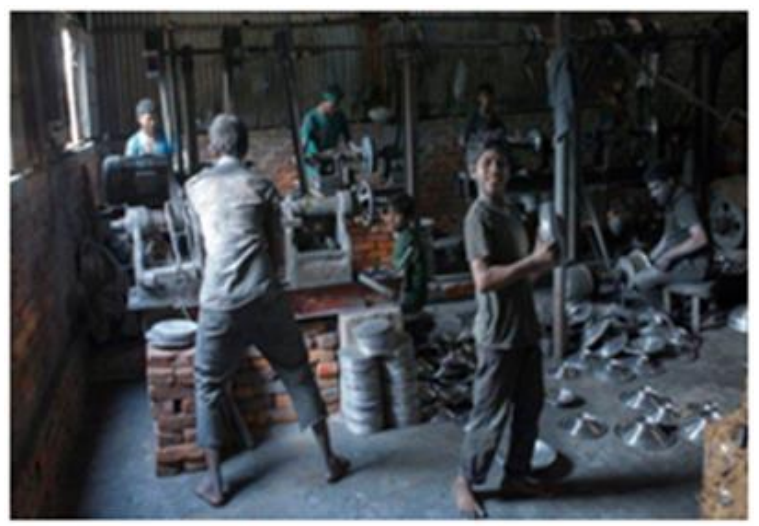

Figure 7. Children as young as 10 operating heavy machinery in a factory in Dhaka, Bangladesh.

The adolescents asserted that Figure 8 [26] did not represent sustainability because the family did not have food to eat and also because of the smoke produced from the coal. Other participants in the group disagreed and explained that the family was making food to sustain themselves and therefore was engaged in a sustainable practice.

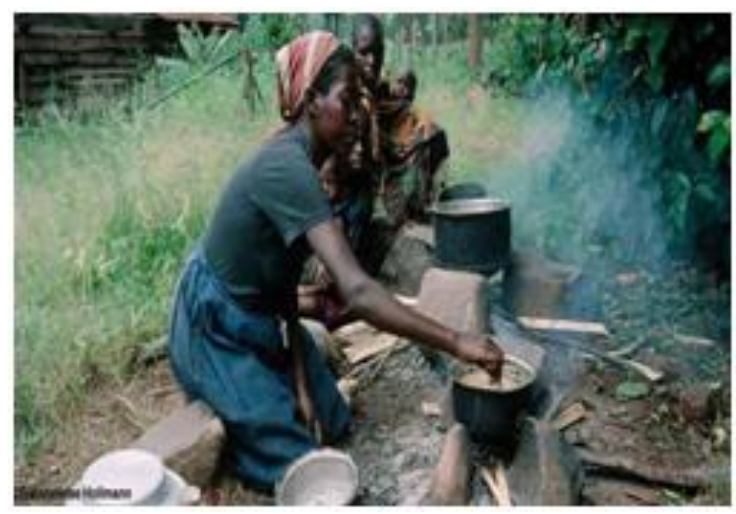

Figure 8. Women and children spend hours near the fire, inhaling toxic smoke during food preparation.

Figure 9 [27] was overall understood to represent industrial air pollution and therefore not a sustainable action. 


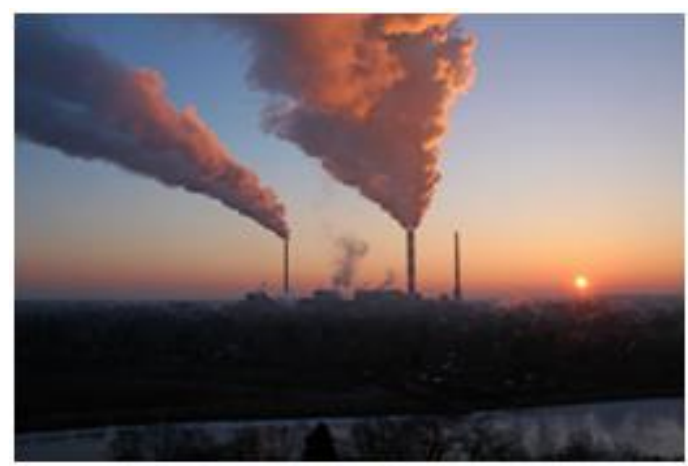

Figure 9. Factory emissions.

As for Figure 10 [28], participants answered that many machines use energy and water, which helps to pollute the environment. Alternatively, others stated that the people in the picture had jobs and could make money to support their families-in which case, the image represented sustainability.

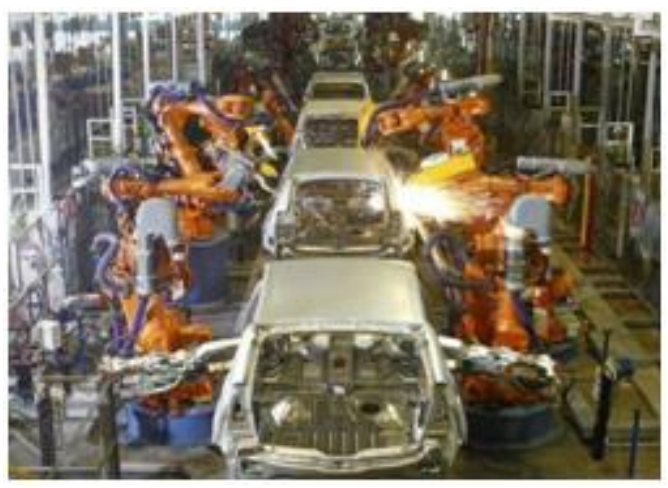

Figure 10. Employees at the Paraná car plant.

The adolescents assumed that Figure 11 [29] was showing sustainability because people have to buy clothes to wear. Interestingly, a debate ensued concerning whether this was in fact a fair assessment since the people in the image seem to be shopping, which, in an affluent consumer society, typically involves consuming more than they actually need.

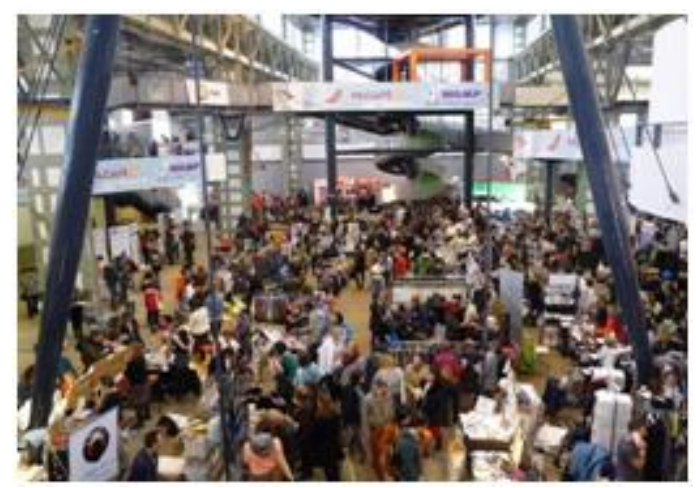

Figure 11. Shoppers in a market.

The adolescents described Figure 12 [30] as representing the unsustainable action of deforestation that in turn increases carbon in the air we breathe. The teenagers also pointed out the relationship between plants, air, and photosynthesis. They explained that photosynthesis enables the carbon dioxide produced by breathing organisms to be used by trees and plants when they produce oxygen, which is then emitted into the atmosphere. 


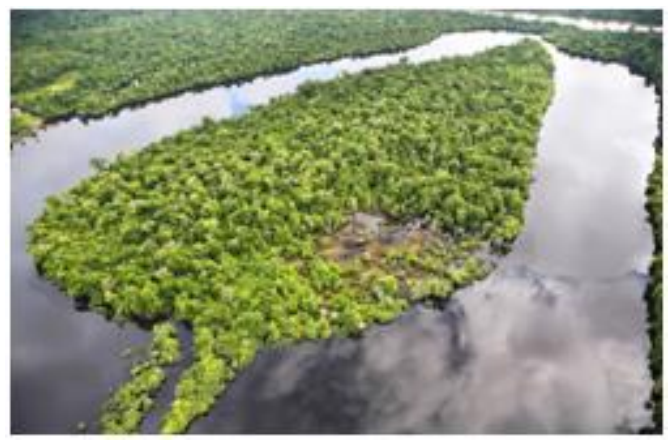

Figure 12. Deforestation in Brazil.

Figure 13 [31] was interpreted as showing agriculture, which could be sustainable or not depending on the processes that were in place. For example, if the farms had utilized pesticides, then they would not be sustainable. Other participants compared the image to a fief, the central element of feudalism. A fief consists of a piece of land given to a vassal by an overlord, to whom the vassal has to provide services (not money) in return. The adolescents perceived that the workers were planting crops to feed other people, rather than themselves. Here, it is important to note that slave-like working conditions are still common in the rural areas of Brazil [32].

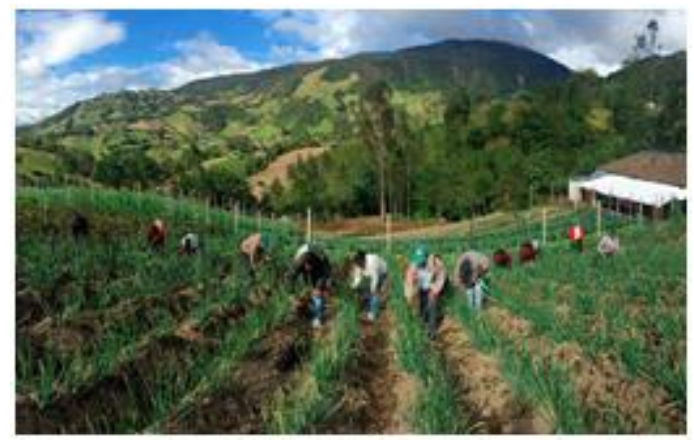

Figure 13. Environmental degradation caused by agricultural production.

For the adolescents, Figure 14 [33] represented bees making honey for healthy living and for selling to acquire the necessary monetary means to live reasonably well (an anthropocentric perception of the illustration).

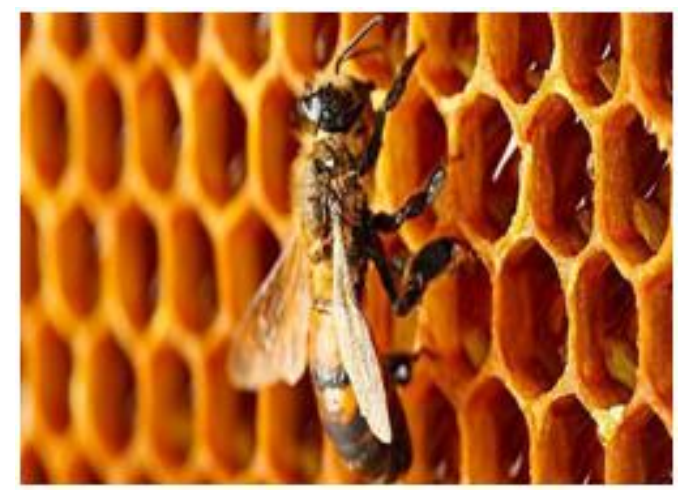

Figure 14. Close-up of a bee and honey comb.

The participants said that Figure 15 [34] was not related to sustainability because the man in the picture looks wealthy. They also described the image as being related to a TV show where a person chooses a box with money that is then used to support their family. Finally, the participants said that 
sustainability is an important word because it is very commonly heard nowadays. They also stated that the man in the picture seemed wealthy because he was well dressed.

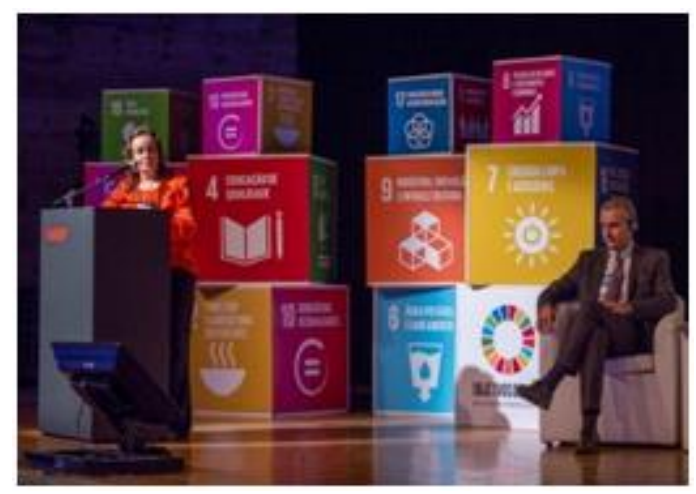

Figure 15. Conference on the sustainable development goals.

\section{Smurfs for the SGDs (Phase 2)}

During the second phase, we learned that the participants were not familiar with the sustainable development goals and the 2030 Agenda. The Smurf's video was an effective tool in teaching the youth about the SGDs because they were already familiar with the Smurfs and they found the video entertaining. The participants enjoyed the process of answering the SDGs quiz. This interactive aspect enabled the youth to think about what SDGs were most relevant to them. It also gave them a feeling of importance since they were choosing the SDG that the Smurf Squad should focus on next. This, in turn, encouraged participants to emulate the Smurf Squad and consider how they could help their community become more sustainable. Accordingly, they decided to create a vertical herbal garden for their own nutritional needs and to learn new skills.

\section{The Vertical Garden (Phase 3)}

When the researchers explained how the plants should be cultivated, the teenagers reacted well to the activity. It seemed to awaken their curiosity as most of the adolescents stated that they had never grown a plant before. At the start none of them knew the difference between a vertical garden and a community garden. Nor did they know if it was necessary to add fertilizer for the plants to grow, or how often they should water the plants. With this in mind, the researchers created a series of activities to help them carry out the garden project. A game was likewise devised to teach them about important characteristics of herbs, including optimal harvest time, ideal temperature for cultivation, and watering frequency. Early into the project, they recognized that it was a way of practicing sustainability. They understood that creating and maintaining a vertical garden in the YC could provide quality herbs - ones that are not grown using agrochemicals or other products that are harmful either to the natural environment or to potential consumers in the community.

For the last activity, the teenagers worked in groups to make posters showing the benefits of the vertical garden to their community and its relation to sustainability. Each group presented their posters to other participants of the project. The first group drew four boxes representing, in order, a car polluting the environment, a plantation, a couple planting a vegetable garden, and deforestation. When this group explained their poster, they argued that vertical gardens can be useful activities that can reduce pollution and enhance natural ecology. In addition, as reflected in the following brief exchange, the group members pointed out the role of the vertical garden in providing food to the YC.

Researcher: What is the importance of the vertical garden to the YC?

Fernando: If we do not have enough food, we do not need to buy more food because we have the garden. Bruno: The community usually does not have enough food. So, it is important to have a garden. [ ... ] Fernando: If there is no food at home and there is no money to buy it, you can harvest food from the garden. 
The second group presented a poster entitled "The importance of cultivation", which highlighted the importance of sustainability and cultivation of the vertical garden. They drew a couple of trees with several corresponding keywords that they considered as a reflection of the project they were engaged in: Love, friendship, friends, community, garden, peace, and family. The group also added names of flowers around a tree and an image of a withered rose. They explained that the image represented what would happen if they did not take care of the vertical garden together: It would die. Another image that they inserted in the poster was a group of people working on a farm. According to the group, this image showed that gardening and sustainability go well together. While presenting their poster, they explained that the herbs grown in the garden were used in the YC kitchen to season the beans and some meat: "The cook, Maria, said that we have used some of the herbs in the meals." This was a source of pride for these youngsters.

The third group explained that the vertical garden was significant because of the oxygen that the plants produced through photosynthesis, cleaning up the pollution in the air, and because of its capacity to feed people. In addition, participants brought up the fact that it was nice to have more green in their community because they did not have many green spaces in their neighborhood. They also claimed that the development of the garden was essential because it taught them how to grow plants:

Molly: I learned how to plant.

Paul: $\quad$ We created lives here.

Researcher: Did you already know how to plant?

Molly: $\quad$ No.

Researcher: Do you like planting?

Molly: Yes.

Researcher: How was it to take care of the garden?

Rebecca: It was really cool. I liked it. It was pretty nice watering the plants.

Additionally, Paul said that he considered the garden important because this activity involved the reuse of the bottles, which he defined as recycling.

In the fourth poster, the group drew an aloe vera indicating that the garden was not only significant for providing food, but it was also used for personal aesthetics, like hair hydration. The fifth poster represented a water treatment station and its relation to watering a garden. By obtaining water from the treatment station, "the garden can grow and offer food to the cook from YC to make it for us." When the group was asked why the development of the garden was important, they talked about the aesthetics of the YC, making it colorful and green, and how watering the plants was so essential for their sustenance. The group also concluded that the YC could in fact build a bigger vertical garden and sell the herbs to the community. The small gains could then be used for the maintenance of the YC.

Similar scholar observations have been made elsewhere [35,36]; it was apparent from the participants' comments that they recognized that green spaces provide cultural and ecological benefits, as well as educational, commercial, recreational and aesthetic advantages.

\section{Discussion}

The vertical garden project enabled us to examine adolescents' views on sustainability and to see how these evolved through the stages of the vertical garden project. At the start of the project, the young people stated that they did not know the meaning of the word "sustainability". During the image activity, they broke the word "sustainability" down into two parts: Sustain + ability. Due to the fact that the word "sustainability" in Portuguese has more than one meaning, the participants interpreted the association of the word "ability" and the phrase "sustain life" with the assurance of meeting one's daily financial and material needs. This was evident when the adolescents described the image of the women cooking (Figure 8). Based on the participants' low socioeconomic status, they associated the idea of sustainability with her work to provide sustenance for herself and her family. This was an example of centric and hierarchical thinking based on the logic of domination and preoccupation with their own immediate needs [16]. By placing their own needs at the center, the youth did not consider sustainability in terms of other life forms and their habitats. This logic of 
human domination was also exemplified by comments such as "bees make honey for humans." The bee image and others like it were often interpreted from a utilitarian human-centric perspective. Likewise, having a job was considered to be sustainable because it is a necessity for one's livelihood. Thus, the image activity revealed that centric thinking underpinned the adolescents' views of sustainability.

The decision to create a vertical garden was a way of encouraging a broader, more holistic view of sustainability. At the start, the participants mentioned that the herbs provided by the garden would be beneficial because they would provide sustenance for themselves, thus enabling them to have input into what they eat. While this view illustrated the youth's centric thinking, it also contributed to a sense of empowerment by allowing them to consider "what they eat as it impacts their health" [37]. Initially, therefore, the value of the vertical garden was rooted in anthropocentric thinking and a utilitarian worldview. Yet, gradually, through engagement in the project, the adolescents expanded their thoughts and were able to consider sustainability in a more holistic way. The use of the PET bottles as planting pots, for example, enabled them to reflect on the notion of recycling as an act of sustainability. The garden also served as a stimulus to discuss broader concerns such as deforestation and the benefits of green spaces, both of which are a highly relevant issue in Brazil.

This shift in thinking, from associating and relegating sustainability solely to immediate human needs to considering the needs of other life forms and the environment that sustains them, was reflected in the way the adolescents cared for the garden. Since it was built on the YC's rooftop where they usually played sports and other informal physical activities, the youth had to protect the garden. As the plants grew, therefore, they agreed that certain activities would be too risky and could potentially harm the plants, so they decided to abstain from sports until the herbs were harvested.

Through their engagement in the garden project, the participating youth were able to gain a broader view of sustainability, one that extended beyond the needs of humans to encompass the needs of other life forms and their habitats. This was very much aligned with the goal of the Science Stand program as a whole, to enable marginalized youth to participate in culturally relevant science demonstrations organized through community/university partnerships. The vertical garden project, albeit small-scale, was nonetheless a transformative learning experience that enabled young people to gain a greater appreciation for science and the natural environment. This was also illustrative of the juxtaposition of EST and EJE. By encouraging youth participation in a project that galvanized their interest and generated benefits for them, while simultaneously leading them to expand their views concerning the meaning of sustainability within the context of their own community, the YC staff and the student researchers associated with the Science Stand program generated a transformative educational experience for the participants. In a small way as well, the project offered insights into the connection between learning and empowerment for marginalized young people-a vision espoused by Mahatma Gandhi, that they could "be the change they wish to see in the world.".

Author Contributions: Investigation, W.C.d.V.S.; Methodology, W.C.d.V.S., L.P.d.C.P. and G.R; Project administration, W.C.d.V.S.; Supervision, L.P.d.C.P. and G.R.; Writing-original draft, W.C.d.V.S., D.S. and L.D.L.d.C.; Writing-review \& editing, W.C.d.V.S., D.S., L.D.L.d.C., L.P.d.C.P. and G.R.

Funding: National Council for Scientific and Technological Development (CNPq) and São Paulo Research Foundation (FAPESP).

Conflicts of Interest: The authors declare no conflict of interest.

\section{References}

1. United Nations. General Assembly. Resolution Adopted by the General Assembly on 27 July 2012. 66/288. The Future We Want. 2012. Available online: http://www.un.org/ga/search/view_doc.asp?symbol=A/RES/66/ 288\&Lang=E (accessed on 12 December 2018).

2. Bodzin, A.; Klein, B.; Weaver, S. (Eds.) The Inclusion of Environmental Education in Science Teacher Education; Springer: Dordrecht, The Netherlands, 2010.

3. Reis, G.; Scott, J. (Eds.) International Perspectives on the Theory and Practice of Environmental Education: A Reader; Springer: New York, NY, USA, 2018. 
4. Piassi, L.P.C.; Vieira, R.M.B.; Santos, E.I. Science stand: Crossing borders between sciences, arts, and humanities in a decentralized science dissemination program. In Crossing the Border of the Traditional Science Curriculum; Pietrocola, M., Gurgel, I., Eds.; Sense Publishers: Rotterdam, The Netherlands, 2017; pp. 73-94.

5. Ferreira, N.C. Experimentoteca ludoteca. In A Universidade e o Aprendizado Escolar de Ciências Projeto USP/BID 1990-1993; CECAE-USP: São Paulo, Brazil, 1993; pp. 97-105.

6. Schwartzman, S.; Micheline, C. A Educação em Ciências No Brasil; Instituto de Estudos do Trabalho e Sociedade (IETS): Rio de Janeiro, Brazil, 2009.

7. Debru, C. Making Education More Inclusive and More Integrated. In Progress in Science, Progress in Society; Tressaud, A., Ed.; Springer: New York, NY, USA, 2018.

8. Gohn, M. Educação não-formal, participação da sociedade civil e estruturas colegiadas nas escolas. Rev. Ens-Aval. Pol. Públ. Educ. 2006, 14, 27-38. [CrossRef]

9. Omasta, M.; Chappell, D. Play matters. In Play, Performance, and Dentity; Omasta, M., Chappell, D., Eds.; Routledge: New York, NY, USA, 2015; pp. 1-21.

10. Moreira, I.C. A inclusão social e a popularização da ciência e tecnologia no Brasil. Incl. Soc. 2006, 1, 11-16.

11. Piassi, L.P.C.; Santos, E.I.; Vieira, R.M.B. Stand of Science: Mobile Communication Science Inquiring about Culture and Society in Schools. Conex. Ciênc. 2017, 12, 306-312. Available online: https://periodicos. uniformg.edu.br:21011/ojs/index.php/conexaociencia/ (accessed on 10 December 2018).

12. IBGE_-Instituto Brasileiro de Geografia e Estatística. Síntese São Paulo, Panorama. 2018. Available online: https://cidades.ibge.gov.br/brasil/sp/sao-paulo/panorama (accessed on 21 December 2018).

13. Atlas of Human Development in Brazil. USP Leste: Ermelino Matarazzo, São Paulo, Brazil, 2010. Available online: http://www.atlasbrasil.org.br/2013/pt/perfil_udh/27641 (accessed on 5 January 2019).

14. Norma Técnica Dos Serviços Socioassistenciais-Proteção Social Básica. Prefeitura de São Paulo: São Paulo, 2012. Available online: https:/www.prefeitura.sp.gov.br/cidade/secretarias/upload/assistencia_social/ arquivos/norma_tecnica.pdf (accessed on 12 December 2018).

15. Desjardins, R. Education and Social Transformation. Eur. J. Educ. 2015, 50, 239-244. [CrossRef]

16. Martusewicz, R.A.; Edmundson, J.; Lupinacci, J. EcoJustice Education: Toward Diverse, Democratic, and Sustainable Community; Routledge: New York, NY, USA, 2011.

17. Hickling-Hudson, A. Teaching to disrupt preconceptions: Education for social justice in the imperial aftermath. Comp. J. Comp. Int. Educ. 2011, 41, 453-465. [CrossRef]

18. Maclure, R.; Sabbah, R.; Lavan, D. Education and development: The perennial contradictions of policy discourse. In Introduction to International Development: Approaches, Actors, and Issues, 2nd ed.; Beaudet, P., Haslam, P.A., Schafer, J., Eds.; Oxford University Press: Toronto, ON, Canada, 2012; pp. 397-412.

19. Brissett, N.; Mitter, R. For Function or Transformation? A Critical Discourse Analysis of Education under the Sustainable Development Goals. J. Crit. Educ. Policy Stud. 2017, 15, 181-204.

20. Andrzejewski, J.; Baltodano, M.; Symcox, L. (Eds.) Social Justice, Peace, and Environmental Education: Transformative Standards; Routledge: New York, NY, USA, 2009.

21. Greenwood, D.A.; Manteaw, B.O.; Smith, G.A. Environmental education from international resolve to local experience and inquiry. In Social Justice, Peace, and Environmental Education: Transformative Standards; Andrzejewski, J., Baltodano, M., Symcox, L., Eds.; Routledge: New York, NY, USA, 2009; pp. 80-98.

22. United Nations. Smurfs Team up with United Nations in 2017 for a Happier, More Peaceful and Equitable World. 2017. Available online: https://www.un.org/sustainabledevelopment/blog/2017/02/smurfs-team-up-with-unitednations-in-2017-for-a-happier-more-peaceful-and-equitable-world/ (accessed on 26 November 2018).

23. Wunder, A. Fotografias Como Exercícios de Olhar; Reunião Anual da Associação de Pós-Graduação e Pesquisa em Educação; ANPED: Caxambu, Brasil, 2006; p. XXIX.

24. McKelvey, D. Child Bathing in Kallyanpur, a Poor Neighborhood of Bangladesh. 2017. Available online: https: //nacoesunidas.org/em-plataforma-global-unesco-divulga-informacoes-sobre-uso-de-recursos-hidricos/ (accessed on 11 December 2018).

25. Hossain Chowdhury, Z. Children as Young as 10 Are Seen Operating Heavy Machinery in a Factory in Dhaka, Bangladesh. 2016. Available online: https:/www.theguardian.com/global-development/2016/dec/07/child-labourbangladesh-factories-rampant-overseas-development-institute-study (accessed on 20 December 2018). 
26. Holllmann, A. Women and Children Spent Hours near the Firte, Inhaling Toxic Smoke that Causes Disease and Leads to Death. 2017. Available online: https://nacoesunidas.org/acnur-e-empresa-ajudam-refugiadosvivendo-em-ruanda-a-trocar-lenha-e-carvao-por-combustivel-limpo/ (accessed on 5 November 2018).

27. PNUMA. International Community Needs to Expand Actions to Combat Climate Change, Says UN Environmental Agency. 2016. Available online: https://nacoesunidas.org/acordo-de-paris-para-o-climaentra-em-vigor-onu-pede-mais-esforcos-na-reducao-de-emissoes/ (accessed on 25 November 2018).

28. Renault. Renault Employs 6500 Employees at the Paraná Plant. 2013. Available online: http://g1.globo.com/pr/parana/noticia/2013/03/renault-inaugura-nova-fabrica-e-amplia-producaode-veiculos-no-pr.html (accessed on 9 December 2018).

29. Estadão Journal Online. Where to Buy Fashionable Clothes. 2016. Available online: https://viagem. estadao.com.br/galerias/geral,as-30-melhores-cidades-no-mundo-para-compras-fashion,27576 (accessed on 10 November 2018).

30. Stirton, B. Deforestation in Brazil. 2011. Available online: https://www.wwf.org.br/?uNewsID=28825 (accessed on 10 December 2018).

31. FAO. Environmental Degradation Caused by Agricultural Production; FAO: Rome, Italy, 2016; Available online: https:/nacoesunidas.org/america-latina-e-caribe-precisam-impedir-degradacao-ambiental-causada-porproducao-agricola-diz-fao/ (accessed on 27 November 2018).

32. Aguiar, M.; Assis, B.; Oliveira, M.; Rosa Filho, D.; Duarte, D. O Dark side no setor rural: Um panorama das condições de trabalho análogas à escravidão no Brasil. Rev. Foco 2019, 12, 4-24. [CrossRef]

33. Animal Ethics. Exploitation of Bees by Humans. Available online: http://www.animal-ethics.org/ animal-exploitation-section/animals-used-food-introduction/exploitation-of-bees-by-humans/ (accessed on 10 December 2018).

34. Abreu, F. Denise Hills Highlighted the Importance of Increasingly Involving Business Leaders in the Quest for Sustainable Development. 2016. Available online: https://nacoesunidas.org/negocios-sustentaveispreservam-planeta-reduzem-desigualdades-e-atraem-consumidores/ (accessed on 10 December 2018).

35. Friess, D.A. Singapore as a long-term case study for tropical urban ecosystem services. Urban Ecosyst. 2017, 20, 277-291. [CrossRef]

36. Steger, C.; Hirsch, S.; Evers, C.; Branoff, B.; Petrova, M.; Nielsen-Pincus, M.; Wardropper, C.; Van Riper, C.J. Ecosystem Services as Boundary Objects for Transdisciplinary Collaboration. Ecol. Econ. 2018, 143, 153-160. [CrossRef]

37. Williams, D.; Brown, J. Learning Gardens and Sustaonability Education: Bringing Life to Schools and Schools to Life; Routledge: New York, NY, USA, 2012. 